ACTA THERIOLOGICA

Vol. 33, 9: 103-114, 1988

\title{
Comparative Morphological Investigations of Forest and Field Ecotypes of Roe Deer in Poland ${ }^{1}$
}

\author{
Reinhold R. HOFMANN, A. S. SABER, Zygmunt PIELOWSKI \\ \& Bogusław FRUZIŃSKI
}

\begin{abstract}
Hofmann R. R., Saber A. S., Pielowski Z. \& Fruziński B., 1988: Comparative morphological investigations of forest and field ecotypes of roe deer in Poland. Acta theriol., 33, 9: 103-114. [With 1 Table, 1 Fig. \& Plates I-IV]

Morphological investigation of kidneys, parotid glands, caecum, rectum, rumen, reticulum and feet in 58 roe deer Capreolus capreolus, shot in the forest $(n=17)$ and in the field $(n=41)$ did not show any significant differences between forest and field ecotypes. There were, however, differences in rumen papillary development, related to seasonal differences in forage quality and availability. Forest roe deer showed a wider range of the papillary surface enlargement factor than field roe deer in summer and had their optimal papillary development in autumn. Field roe deer showed a reduction of absorptive ruminal surface from summer to winter of almost $\mathbf{5 0} \%$. Their adaptive range is within that of the species and does not indicate the ecotype separation.

[Dept. Comparative Anatomy, Domestic and Wild Animals, Inst. Vet. Anatomy, Histology, Embryology, University of Giessen, Frankfurter Strasse 98, 6300 Giessen, FRG (BRH), Dept. of Veterinary Anatomy, Assiut University, Assiut, Egypt (ASS), Polish Hunting Association, Research Station, Sokolnicza 12, 62-055 Czempiń (ZP), Dept. Game Management, Academy of Agriculture, Wojska Polskiego 71d, 60-625 Poznań, Poland (BF)].
\end{abstract}

\section{INTRODUCTION}

Roe deer, Capreolus capreolus (Linnaeus, 1758) is an ancient small ruminant species which shows a series of behavioural and physiological adaptations enabling it to survive Eurasian climates. Such adaptations have a well developed morphological base, like the resting blastocyst ("delayed implantation"), the air-containing winter coat and a typical concentrate selector's digestive system (Hofmann, 1985).

When a separation of roe deer into field-type and forest-type was observed, the question arose as to what extent the development of the field ecotype had already influenced the anatomy of this species. Differences observed in feeding and flight behaviour directed our attention to comparative investigation of the digestive system, kidneys and feet, of roe deer from the two habitats.

1 Praca wykonana w ramach problemu MR.II.15 koordynowanego przez Instytut Ekologii PAN. 


\section{MATERIAL AND METHODS}

Between October 1980 and October 1981, a total of 58 roe deer, shot in two Polish game research areas were used for this study. Seventeen animals came from a mixed forest area (Zielonka) while 41 came from a well monitored field roe population (Czempiń): 30 were males and 28 were females. Only two animals were less than one year old while 12 were from one to two years old. The remaining 44 animals were between 2 and 10 years old. In order to observe possible seasonal influences, the animals were collected at certain periods simultaneously in both areas; early October; end of January; end of May July/August.

As quickly as possible after the animals' death (usually within the first hour) the following specimens were cut out and fixed in a $4 \%$ formaldehyde: (1) one thin slice (cross section) from the centre (hilus) of one kidney, (2) small sample of glandular tissue from the centre of the parotid gland, (3) the blunt apex of the caecum, i.e. entire wall of the large intestine, appr. $3 \times 3 \mathrm{~cm},(4)$ a transverse section from the rectum, $2-3 \mathrm{~cm}$ long, (5) four samples from the rumen wall and one sample from the reticulum. The rumen samples were taken from four homologue test regions (as identified by Hofmann, 1973) indicating the current nutritional status or evolutionary adaptations (Hofmann et al. 1976, 1982). These samples (appr. $5 \times 7 \mathrm{~cm}$ rectangular pieces) were: (1) dorsal ruminal wall, (2) atrium ruminis, (3) caudoventral blindsac, and (4) ventral ruminal wall.

One foot from the fore- and hindleg of each animal, was cut off at the carpal and tarsal joints, respectively, and were preserved in $5 \%$ formaldehyde solution.

The histological samples, as listed under points 1-4 were trimmed to size, dehydrated and embedded in paraffin. Microtome sections appr. $6-8 \mu \mathrm{m}$ were stained with haemotoxylin-eosin for comparative rolitine microscopic investigation, according to Lackhoff (1983), Ludwing (1986), and Thomé (1988).

The ruminoreticular samples were used for mucosal photography as described by Hofmann $(1969,1973)$ while a stencil was applied to cut out a mucosal sample $10 \times 10 \mathrm{~mm}$ for counting and measuring ruminal papillae and calculating the surface enlargement factor (SEF) from each of the four test regions, following the technique of Hofmann et al. (1976) and König et al. (1976).

The preserved feet were dissected and measured as described by Czöndör (1973) and compared with feet from other roe deer and with the results published by Habermehl (1958).

\section{RESULTS}

\subsection{Kidney}

Roe deer have a highly fused kidney with a smooth surface and a renal crest, very similar to the kidneys of the domesticated goat and sheep (Schummer, 1975). There are, however, general differences in the proportions of medullary and cortical tissue, the number and size of renal corpuscles and the structure and distribution of renal blood vessels, which are the subject of a comparative study on ruminant kidneys. No significant morphological differences were observed, within a range of 
normal intraspecific variation, between kidney tissue samples from roe deer of forest type (FoT) and field type (FiT).

\subsection{Parotid Gland}

As was shown by Ramisch (1978), roe deer have a very large parotid gland making up $0.22 \%$ of the body weight. This was later confirmed by Kay et al. (1980) who calculated metabolic weight of this organ as $4.7 \mathrm{~g} / \mathrm{kg}$ body weight 0.75 . These values are within the range of all the other small and middle-sized concentrate selectors with a small rumen capacity and high fermentation rates (Hofmann, 1984). The microstructure of the roe deer parotid gland, a purely serous tubulo-alveolar gland with striated ducts, did not differ between FoT and FiT. Some minor differences in vascularization, size of cells and nuclei, seen between animals from summer/autumn, as opposed to some collected in winter, could not be substantiated due to the small number of animals available.

\subsection{Caecum}

The caecum and the initial, wide portion of the ascending colon (ansa proximalis coli) are used in roe deer and other concentrate selectors as a distal (second) fermentation chamber (Drescher-Kaden, 1976; Hoffmann, 1977; Hoppe et al., 1983; Hofmann, 1985). The average capacity of the roe deer caecum is $393 \mathrm{ml}$ (Hofmann, 1977). This gives a ratio of $1: 8-10$ to the rumino-reticular capacity (proximal fermentation chamber). Here cellulolytic microbial breakdown occurs of forb and foliage hemicelluloses (Ulyatt et al., 1975) which have escaped ruminal fermentation. Comparison of FoT and FiT tissue samples with the detailed histological results of Lackhoff (1983) and Ludwig (1986) showed complete agreement, including variations between animals under summer- or winter feeding conditions.

The muscular tunic, although frequently damaged, was within the thickness range given by Lackhoff; i.e. 304.21-405.96 $\mu \mathrm{m}$. Also the average lenght of the Lieberkühn crypts given as $450.44 \mu \mathrm{m}$ (range: 278.25-628.97) conforms to the Polish deer tissue measurements. Similarly, the surface epithelium (range 11.87-23.73 $\mu \mathrm{m}$ ) and the percentage of goblet cells of the total epithelial cell count does not deviate from the data established by Lackhoff (1983): on average 56.50\% (range 40.00$-73.67 \%$ ). There were also a thinner muscular tunic, a thinner mucosa and fewer goblet cells in the winter samples, which was also within the range given by Lackhoff (1983) and by Ludwig (1986). Measurements taken in FoT did not differ, within the same range, from those taken in FiT. 
Table 1

Papillary measurements from the field and forest roe deer. SEF - surface enlargement factor. See text for explanation.

\begin{tabular}{|c|c|c|c|c|c|c|c|}
\hline \multirow{2}{*}{ No. } & \multirow{2}{*}{ Date } & \multirow{2}{*}{ Age } & \multicolumn{4}{|c|}{ SEF/sample: } & \multirow{2}{*}{$\begin{array}{l}\text { Mean } \\
\text { SEF }\end{array}$} \\
\hline & & & 1 & 2 & 3 & 4 & \\
\hline \multicolumn{8}{|c|}{ Field roe deer } \\
\hline 1 & $10 / 80$ & $>10$ & 11.05 & 8.70 & 10.00 & 9.18 & 9.73 \\
\hline 2 & $10 / 80$ & 0.5 & 9.90 & 6.39 & 13.00 & 14.10 & 10.85 \\
\hline 3 & $10 / 80$ & $2-3$ & 9.30 & 9.36 & 11.67 & 9.03 & 9.84 \\
\hline 4 & $10 / 80$ & $8-10$ & 9.58 & 9.33 & 7.64 & 7.62 & 8.54 \\
\hline 5 & $10 / 80$ & $3-4$ & 6.52 & 9.68 & 7.24 & 10.39 & 8.46 \\
\hline 6 & $10 / 80$ & 0.5 & 7.40 & 18.33 & 8.56 & 12.70 & 11.75 \\
\hline 7 & $10 / 80$ & $3-4$ & 6.58 & 25.70 & 14.44 & 12.20 & 14.73 \\
\hline 8 & $10 / 80$ & $7-8$ & 10.01 & 11.08 & 9.96 & 9.78 & 10.21 \\
\hline 9 & $10 / 80$ & $6-7$ & 11.65 & 11.98 & 10.79 & 5.48 & 9.98 \\
\hline 10 & $10 / 80$ & $1-2$ & 5.13 & 11.14 & 11.50 & 9.25 & 9.26 \\
\hline 11 & $10 / 80$ & $3-4$ & 8.92 & 7.12 & 12.06 & 4.66 & 8.19 \\
\hline 12 & $10 / 80$ & $4-5$ & 6.72 & 6.31 & 13.96 & 11.44 & 9.61 \\
\hline 13 & $10 / 80$ & $3-4$ & 14.68 & 7.63 & 13.42 & 11.50 & 11.81 \\
\hline 14 & $1 / 81$ & $7-8$ & 6.00 & 8.44 & 5.60 & 7.48 & 6.63 \\
\hline 15 & $1 / 81$ & $4-5$ & 6.16 & 10.60 & 7.85 & 6.58 & 7.80 \\
\hline 16 & $1 / 81$ & $8-10$ & 4.12 & 8.92 & 5.27 & 6.04 & 6.09 \\
\hline 17 & $1 / 81$ & $8-10$ & 6.70 & 10.75 & 6.25 & 5.40 & 7.28 \\
\hline 18 & $1 / 81$ & $1-2$ & 3.40 & 9.91 & 4.99 & 3.76 & 8.01 \\
\hline 19 & $1 / 81$ & 1 & 5.77 & 8.65 & 7.00 & 3.45 & 6.22 \\
\hline 20 & $1 / 81$ & 1 & 6.06 & 6.20 & 8.05 & 9.50 & 7.45 \\
\hline 21 & $1 / 81$ & $2-3$ & 8.43 & 8.48 & 5.70 & 6.77 & 7.35 \\
\hline 22 & $1 / 81$ & $4-5$ & 4.40 & 9.58 & 4.65 & 4.60 & 5.81 \\
\hline 23 & $1 / 81$ & $8-10$ & 6.16 & 3.66 & 3.52 & 4.60 & 4.49 \\
\hline 24 & $5 / 81$ & $3-4$ & 7.00 & 4.29 & 6.88 & 9.25 & 6.89 \\
\hline 25 & $5 / 81$ & $5-6$ & 11.64 & 17.50 & 18.72 & 11.96 & 16.96 \\
\hline 26 & $5 / 81$ & 1 & 9.40 & 18.16 & 7.20 & 11.26 & 11.51 \\
\hline 27 & $5 / 81$ & $3-4$ & 4.66 & 8.48 & 9.10 & 9.25 & 7.87 \\
\hline 28 & $5 / 81$ & $5-6$ & 13.72 & 15.07 & 9.75 & 8.92 & 10.87 \\
\hline 29 & $5 / 81$ & $5-6$ & 9.22 & 20.39 & 6.76 & 11.08 & 11.86 \\
\hline 30 & $5 / 81$ & $4-5$ & 10.30 & 9.10 & 6.04 & 6.92 & 8.09 \\
\hline 31 & $5 / 81$ & $4-5$ & 14.86 & 15.04 & 10.10 & 10.80 & 12.70 \\
\hline 32 & $6 / 81$ & $2-3$ & 18.76 & 16.75 & 13.16 & 14.86 & 15.88 \\
\hline 33 & $6 / 81$ & $3-4$ & 10.36 & 10.54 & 12.70 & 6.84 & 10.11 \\
\hline 34 & $6 / 81$ & $9-10$ & 8.04 & 8.20 & 11.07 & 7.72 & 8.76 \\
\hline 35 & $8 / 81$ & 1 & 4.36 & 8.80 & 5.06 & 8.11 & 6.58 \\
\hline 36 & $8 / 81$ & 1 & 6.52 & 5.40 & 5.30 & 4.99 & 555 \\
\hline 37 & $8 / 81$ & $8-10$ & 5.55 & 11.53 & 7.23 & 8.80 & 8.28 \\
\hline 38 & $8 / 81$ & 2 & 12.34 & 16.84 & 16.68 & 14.07 & 14.98 \\
\hline 39 & $8 / 81$ & $3-4$ & 8.20 & 9.61 & 5.29 & 8.38 & 7.87 \\
\hline 40 & $8 / 81$ & $3-4$ & 6.76 & 12.35 & 12.52 & 5.41 & 9.26 \\
\hline 41 & $8 / 81$ & $5-6$ & 9.74 & 11.56 & 8.00 & 8.50 & 9.45 \\
\hline \multicolumn{8}{|c|}{ Forest roe deer } \\
\hline 1 & $10 / 80$ & $5-6$ & 10.60 & 14.46 & 10.36 & 8.10 & 11.13 \\
\hline 2 & $10 / 80$ & $4-5$ & 5.18 & 10.36 & 7.96 & 5.94 & 7.36 \\
\hline 3 & $10 / 80$ & $3-4$ & 5.56 & 12.98 & 8.97 & 12.61 & 10.03 \\
\hline 4 & $10 / 80$ & $1-2$ & 10.00 & 12.70 & 8.41 & 12.34 & 10.86 \\
\hline 5 & $10 / 80$ & $5-6$ & 7.75 & 10.00 & 10.24 & 4.95 & 8.24 \\
\hline 6 & $6 / 81$ & 1 & 13.32 & 16.84 & 20.50 & 15.52 & 16.55 \\
\hline 7 & $7 / 81$ & 1 & 7.80 & 9.60 & 7.40 & 7.93 & 8.18 \\
\hline 8 & $7 / 81$ & 2 & 10.84 & 12.40 & 7.27 & 9.24 & 9.94 \\
\hline 9 & $7 / 81$ & $7-8$ & 17.01 & 20.44 & 18.15 & 14.86 & 17.87 \\
\hline 10 & $7 / 81$ & $3-4$ & 13.96 & 15.63 & 12.34 & 12.55 & 13.62 \\
\hline
\end{tabular}


Table 1. concluded.

\begin{tabular}{rrrrrrrr}
\hline 11 & $7 / 81$ & $6-7$ & 5.32 & 7.30 & 5.08 & 5.06 & 5.69 \\
12 & $7 / 81$ & & 5.22 & 5.76 & 7.50 & 6.53 & 6.50 \\
13 & $7 / 81$ & $4-5$ & 10.76 & 15.80 & 14.44 & 15.70 & 14.18 \\
14 & $8 / 81$ & $7-8$ & 4.64 & 5.58 & 7.11 & 6.10 & 6.11 \\
15 & $9 / 81$ & 8 & 8.07 & 7.34 & 7.78 & 4.84 & 9.51 \\
16 & $9 / 81$ & $3-4$ & 9.51 & 20.80 & 16.39 & 11.80 & 14.63 \\
17 & $9 / 81$ & $1-2$ & 10.84 & 10.48 & 13.21 & 8.04 & 10.64 \\
\hline
\end{tabular}

\subsection{Rectum}

The roe deer rectum shows a number of typical features (cf. Hoffmann, 1977, Lackhoff, 1983). Its adventitia is the site of extensive deposits of adipose tissue (perirectal, subserous depot fat) especially between September and January (Hoffmann, 1977). These were found in the samples used in this study, but they could not be quantified with histological methods. Animals shot in October showed fat lobules extending into the intermuscular septa of the stratum longitudinale of the muscular tunic as noted by Lackhoff (1983).

The relatively thick tunica muscularis was weaker in animals from winter $(426.59-738.57 \mu \mathrm{m})$ then those from summer $(786.12-1011.10 \mu \mathrm{m})$, both within the ranges given by Lackhoff. There were no samples of FoT from winter. Fot and FiT from summer, on the other hand, did not differ in any of the morphological data taken. Lieberkühn crypts were within the lenght range given by Lackhoff $(404-629)$. There were also (within the range of $61.00-82.67 \%$ ) no differences observed in the proportion of rectal goblet cells between FoT and FiT.

\subsection{Ruminoreticulum}

It has been shown by many authors that the absorptive ruminal mucosa of both domestic and wild ruminants reacts to changes in diet quality (plant cell content, plant cell wall proportion, digestibility), by distinct morphological changes (review: Hofmann \& Schnorr, 1982). Such changes were recorded for roe deer by Hofmann et al. (1976) and König et al (1976). Since the ruminal mucosa of four physiologically different test regions (Hofmann et al., 1982) appears to be a rather sensitive indicator for forage quality differences, papillary measurements of all animals in this study were recorded (Table 1). The changes of the surface enlargement factor (SEF) are illustrated by Fig. 1.

The maximal single surface enlargement was found in the atrium ruminis sample (region 2) of a 4 year-old FiT buck shot on 8th October: $25.70 \times$. The minimum was found on the dorsal ruminal wall (region 1) of a ca. 19 months old doe shot on 29th January: $3.40 \times$. The average $\mathrm{SEF}$, calculated from the four indicator regions clearly reflected seasonal 
nutritional changes both in the forest and field ecotypes of roe deer (Fig. 1).

In October of the first year, the maximum SEF was. 11.13 in FoT and 14.73 in FiT, and the minimum 7.36 and 8.19 , respectively. There were winter data (end of January) for FiT only (maximum 8.01, minimum 4.49). This amounts to an effective surface reduction from summer to winter of almost $50 \%$.

During optimal vegetation development (end of May, early July) and optimal availability in the forb layer, FoT roe deer showed a somewhat wider average SEF-range than FIT roe deer: $5.69-17.87$ vs. $6.89-15.88$, respectively. At the end of the rut (middle of August), there was a marked surface reduction with upper (14.98) and lower (5.55) extremes in juvenile bucks which presumably did not participate in rutting. Both FiT and FoT increased their absorptive surface again after the rut and into the autumn (maximum $14.63 \times$, minimum $6.11 \times$ ) of the second year, this time with a wider range.

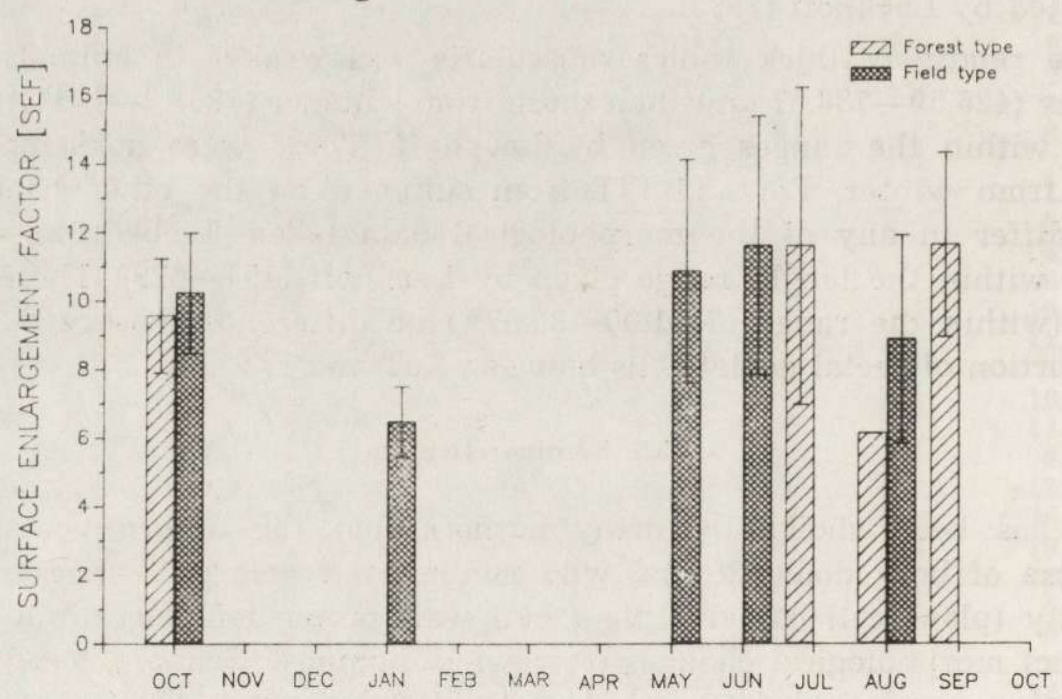

Fig. 1. Rumen papillary development changes under the influence of changing forage quality and seasonal changes in food intake, as expressed by the SEF mean of four homologue indicator regions from 58 Polish roe deer.

König et al. (1976) showed that an average SEF in roe deer $(n=20)$ ranged from 4.10 to 11.00 and was on average of $36 \%$ higher in summer than in winter. The average SEF for the studied series of roe deer $(n=58)$ had on overall range from 4.49 to 17.87 . FoT roe deer showed a slightly greater diversity (5.69 to 17.87 ) than FiT (4.49 to 15.88$)$. These mucosal differences, especially within a sampled group, could not be detected by adspection or by photographic documentation only (Plates 
I-IV). There were, however, obvious morphological changes relating both to size and density of the papillae but they require quantification (SEF).

\subsection{Fore- and Hind-Foot Structure}

Based on the available literature and specimens for comparison from various roe deer areas in Germany, a detailed study was carried out in order to detect possible structural adaptations of the acropodium to the field habitat. Hair arrangement, length (ff 9-21 $\mathrm{mm}$; hf $12-24 \mathrm{~mm}$ ) and coloration were considered. All FiT data were within the range of FoT data. The metatarsal gland, $7-11 \mathrm{~cm}$ below the tuber calcanei, visible as an elevated hair area $(23-25 \times 30-45 \mathrm{~mm}$ in size) showed size and colour variations in FiT typical also for FoT. Not one of the FiT bone measurements (metacarpus and phalanges; metatarsus and phalanges) differed from the data established by Thomas (1983). There were no differences in the measurements of the hooves (length, height, angles, sole, pulvinum) between FoT and FiT. Landolt (1915) observed a distinct morphophysiological adaptation of the hooves of alpine cattle as opposed to lowland cattle, which might suggest adaptive variations in other ruminants, e.g. roe deer. The development of the main flexor and extensor tendons (which show functionally induced differences, e.g. between cattle and moose (Kendelbacher, 1935) and which was described for roe deer by Habermehl (1958), corresponds in both FiT and FoT.

\section{DISCUSSION}

The field ecotype of roe deer shows a distinct behavioural and spatial separation from the forest ecotype (Pielowski, 1984). It differs also in body weight and length from forest ecotype roe deer (Fruziński et al., 1982) but not in other parameters. These differences may be related to better feeding conditions. During the vegetation period, the field habitat offers simultaneously food and cover, which saves energy. A study by Kałuziński (1982) showed that in agrocenosis there is the typical food plant diversity, but selective feeding by roe deer centres mainly upon six species of cultivated plants. Seasonal changes of selected plants relate to changes in their digestibility, as in other habitats. There are slight differences in the biochemical properties and responses between the two ecotypes (Majewska et al., 1982). It appers, however, from our present study, that the separation of roe deer into a forest and field ecotype has not yet led to significant morphophysiological adaptations. Roe deer exhibit a remarkable adaptability to different habitats or environmental pressures. 
Kidney tissue was selected due to possible differences in water and mineral metabolism, which obviously are within the adaptive range of the species.

The big parotid gland plays an important role in buffering the fermentation products (short-chain fatty acids) of the roe deer's high amylolytic fermentation rates (Kay et al., 1980) and may be used in bypassing water soluble nutrients via the ventricular groove (Hofmann, 1984), or its secretion maybe neutralizing tannin or other phenolic passing water soluble nutrients via the ventricular groove (Hofmann, 1988). Again, such physiological differences have not altered the species' structural principles, although there are indications that, in ruminants salivary gland tissue responds to seasonal changes.

Different food plant selection as shown by Kałuziński (1982) would imply a different course of physiological and biochemical events along the digestive tract, especially in relation to ruminal escape. Hypothetically, roe deer may have to digest more hemicelluloses in the forest than in the fields.

The results of the rumen mucosa and SEF analyses showed that in general better nutritional conditions for roe deer prevailed in Poland than in the Federal Republic of Germany (cf. data by Hofmann et al., 1976; König et al., 1976). They also may reflect the influence of territorialism on nutrition, perhaps more so in the FoT. The latter perhaps show a wider range between optimal and poor forage quality available within their territorial system. The temporary drop in the absorptive surface of the ruminal mucosa around the rut was caused by a behaviourally induced poorer food intake of mature bucks. The lowest value during this period was from a (supressed?) yearling, and the highest from a two year old buck which may not have participated in rutting but continued feeding, and stayed on the high nutritional level as observed most bucks in late May/early June.

Although few data are available, it appears that FoT may have better feeding conditions in autumn than FiT. There is a well known tendency in roe deer to replenish energy reserves depleted during the early rut (July/August) from fruits, nuts, acorns and other nutritious plant products. Their high starch and fat contents help to accumulate fat ("autumn mast") as a compensation for poor winter forage, reduced activity and reduced metabolism (Weiner, 1977; Hofmann \& Kirsten, 1982; Deipenbrock, 1986).

The undisputed stimulatory effect of butyric and propionic acid upon rumen blood flow and, eventually, on papillary development appears to be extremely dramatic at times. Several of the samples used for SEF calculations showed abnormal papillae (Plate IV) which appeared to have 
grown so rapidly, that their epithelial coating did not separate at the base of adjacently growing papillae. In FoT they were found under optimal summer feeding conditions, and in FiT' in May. Papillary growth is initiated by changes in the subepithelial vascular system (Hofmann et al., 1976; Amasaki, Daigo \& Hayashi, 1986) which induces epithelial cell proliferation. In contrast, reduced blood flow under poorer feeding conditions results in poorer papillary blood supply, multiple cell death which reduces the size and number of papillae, i.e. a smaller SEF.

There is no indication that rumen mucosal responses in roe deer of different ecotypes are different. It may be, that FiT live under more even feeding conditions in autumn and winter than FoT. But FiT are as diversified as FoT (in summer), when suitable forage is available. From a diagnostic point of view, however, it is not possible to distinguish the ruminal mucosa of $\mathrm{FiT}$ and $\mathrm{FoT}$ at any time of the year.

\section{REFERENCES}

1. Amasaki H., Daigo M. Hayashi K., 1986: Prenatal development of ruminal microvasculature related to morphogenesis of ruminal papillae. Comparative aspects of physiology of digestion in ruminants. Cornell University. 38-39.

2. Czöndör J., 1973: Vergleichend-anatomische Untersuchungen am Vorder und Hinterfuss des Rotwildes (Cervus elaphus hippelaphus Erxleben, 1977) einschliesslich diagnostischer Merkmale. Dissert. Vet. Med. Univ. Giessen.

3. Deipenbrock P. H., 1986: Morphologische Untersuchungen zu Wachstum und Kondition des Rehwildes (Capreolus capreolus Linné, 1758) in einer Hegegemeinschaft im nördlichen Rheinland-Pfalz. Dissert. Vet. Med. Univ. Giessen.

4. Drescher-Kaden U., 1976: Untersuchungen am Verdauungstrakt von Reh, Damhirsch und Mufflon; Mitt. 1: Gewichtserhebungen und Kapazitätsmessungen, insbesondere am Pansen-Hauben-Raum. Z. Jagdwiss., 22: 184-190.

5. Fruziński B., Kałuziński J. \& Baksalary J., 1982: Weight and body measurements of forest and field roe deer. Acta theriol., 27: 479-488.

6. Habermehl K. H., 1958: Morphologische Unterschiede zwischen Vorder- und Hinterlauf beim Reh (Capreolus capreolus L.). Berliner u. Münchner tierärztl. Wochenschr., 71: 89-90.

7. Hoffmann R., 1977: Morphologische Untersuchungen am Darm des Rehes, Capreolus capreolus (Linné, 1758) einschliesslich der assozierten Strukturen. Schriften Arbeitskreis Wildbiologie und Jagdwissenschaft a.d. Justus LiebigUniversität Giessen, 2: 1-93. Ferdinand Enke-Verlag Stuttgart.

8. Hofmann R. R., 1969: Zur Topographie und Morphologie des Wiederkäuermagens im Hinblick auf seine Funktion (nach vergleichenden Untersuchungen an Material ostafrikanischer Wildarten). Zentralblatt f. Vet. Med., Paul Parey, Berlin und Hamburg, 1-180.

9. Hofmann R. R., 1973: The ruminant stomach. Stomach structure and feeding habits of East African game ruminants. East African Monographs in Biology, E. A. Lit. Bureau, Nairobi, Vol. 2: 1-364.

10. Hofmann R. R., 1984: Comparative anatomical studies imply adaptive variations 
of ruminant digestive physiology. Can. J. Anim. Sci., 64 (Suppl.): 203-205.

11. Hofmann R. R., 1985: Digestive physiology of the deer - their morpho-physiological specialisation and adaptation. [In: "Proceed. Internat. Conference on the Biology of Dear Production", Ed. K. Drew, P. Fennessy], Royal Soc. New Zealand Bull., 22: 393-407.

12. Hofmann R. R., 1988: Morphophysiological evolutionary adaptations of the ruminant digestive system. [In: "Aspects of digestive physiology in Ruminants", A. Dobson \& M. J. Dobson, Eds.]. Cornel Univ. Press: 1-20.

13. Hofmann R. R., König R. \& Geiger G., 1976: Differentiellmorphologische Untersuchungen der resorbierenden Schleimhautoberfläche des Pansens beim Rehwild (Capreolus capreolus) im Sommer und Winter. Z. Jagdwiss., 22: $191-196$

14. Hofmann R. R. \& Kirsten N., 1982: Die Herbstmast-Simulation. Schriften des Arbeitskreises Wildbiologie u. Jagdwissenschaft a.d. Justus Liebig-Universität Giessen, Heft 9: 1-113. Ferdinand Enke-Verlag Stuttgart.

15. Hofmann R. R. \& Schnorr B., 1982: Funktionelle Morphologie des Wiederkäuer-Magens (Schleimhaut und Versorgungsbahnen): Ferd. Enke-Verlag, Stuttgart, $1-160$.

16. Hoppe P., van Hoven W., von Engelhardt W., Prins R. A., Lankhorst A. \& Gwynne M. D., 1983: Pregastric and caecal fermentation in dikdik (Madoqua kirki) and suni (Nesotragus moschatus). Comp. Biochem. Physiol., 75A: 517-524 .

17. Kałuziński J., 1982: Composition of the food of roe deer living in fields and the effects of their feeding on plant production. Acta theriol., 27: 457-470.

18. Kay R. N. B., von Engelhardt W. \& White R. G., 1980: The digestive physiology of wild ruminants. [In: "Digestive Physiology and Metabolism in Ruminants", Y. Ruckebusch \& P. Thivend, Eds.]. MTP Press, Lancaster: 743-761.

19. Kendelbacher E., 1935: Vergleichend-anatomische und histologische Untersuchungen am Vorder- und Hinterfuss von Rind und Elch. Vet. Med. Dissertation Univ. Giessen.

20. König R., Hofmann R. R. \& Geiger G., 1976: Differentielmorphologische Untersuchungen der resorbierenden Schleimhautoberfläche des Pansens beim Rehwild (Capreolus capreolus) in Sommer und Winter. Z. Jagdwiss., 22: 191-196.

21. Lackhoff M., 1983: Vergleichende histologische und morphometrische Untersuchungen am Darm von Rehwild (Capreolus capreolus Linné, 1758) und Buschschliefer (Heterohyrax syriacus). Vet. Med. Dissertation, Univ. Giessen.

22. Landolt K., 1945: Über die Afterklauen des Rindes mit besonderer Berücksichtigung ihrer funktionellen Bedeutung. Vet. Med. Dissertation Univ. Zürich.

23. Ludwig J., 1986: Vergleichende histologische und morphometrische Untersuchungen am Dickdarm von 30 Wiederkäuerarten (Ruminantia Scopoli, 1977). Vet. Med. Dissertation Univ. Giessen.

24. Majewska B., Pielowski Z. \& Labudzki L., 1982: The level of some energy metabolism indices in forest and field populations of roe deer. Acta theriol., 27: $471-477$.

25. Pielowski Z., 1983: Some aspects of population structure and longevity of field roe deer. Acta theriol., 29: 17-33.

26. Ramisch., 1978: Topographische und funktionelle Anatomie der Kaumuskeln und der Speicheldrüsen des Rehes, Capreolus capreolus (Linné, 1758). Schriften Arbeitskreis Wildbiologie u. Jagdwissenschaft a.d. Justus Liebig-Universität Giessen, Ferdinand Enke-Verlag Stuttgart., 3: 1-104.

27. Schummer A., 1975: Harnorgane [In: "Nickel-Schummer-Seiferle, Lehrbuch der 
Anatomie der Haustiere"]. Bd. 2, 3. Aufl. Verlag Paul Parey, Berlin und Hamburg.

28. Thomas R., 1988: Die Möglichkeiten der Altersbestimmung beim Rehwild, Capreolus capreolus L. anhand der Skelettentwicklung. Vet. Med. Dissertation Univ. Giessen.

29. Thomé M., 1986: Vergleichend-histologische und morphometrische Untersuchungen an den Speicheldrüsen der Wiederkäuer (Ruminantia Scopoli, 1777). Vet. Med. Disseration Univ. Giesen.

30. Van Soest P. J., 1982: Nutritional ecology of the ruminant. O \& B Book, Corvallis, Oregon.

31. Weiner J., 1977: Energy metabolism of the roe deer. Acta theriol., 22: 3-24.

Received 3 December 1986, Accepted 20 May 1987.

Reinhold R. HOFMANN, A. S. SABER, Zygmunt PIELOWSKI

i Bogusław FRUZIŃSKI

\section{PORÓWNAWCZE BADANIA MORFOLOGICZNE NAD LESNYMI I POLNYM EKOTYPEIM SARNY W POLSCE}

Streszczenie

W ramach prac badawczych nad biologicznym różnicowaniem się dwóch form ekologicznych sarny przeprowadzono również badania nad morfologią tego gatunku, ze szczególnym uwzględnieniem przewodu pokarmowego i związanych z nim narządów wewnętrznych.

W latach 1980 i 1981 zebrano 17 sarn leśnych z lowiska doświadczalnego Zielonka i 41 sarn polnych z lowiska doświadczalnego Czempiń. Od każdego osobnika pobrano wycinki nerek, gruczolów ślinowych, jelita ślepego, prostnicy i żwacza, oraz część skokową przednich i tylnych kończyn. Różnice morfologiczne stwierdzono jedynie w rozwoju kosmków na ścianach żwacza (Tabela 1, Ryc. 1, Tablice I-IV), związane z sezonowo zróżnicowaną jakością i dostępnością żeru obu ekotypów. Sarnę leśną cechuje w okresie letnim większy rozrzut wartości wskaźnika powiększenia powierzchni kosmków (SEF), niż u sarny polnej. Swój największy rozwój ma on w okresie jesieni. Sarna polna wykazuje między latem a zimą redukcję powierzchni chłonnej żwacza o prawie $50 \%$. Znaczenie przystosowawcze tego zjawiska zdaje się jednak dotyczyć całego gatunku. Nie jest ono zatem wskaźnikiem separacji ekotypowej. 


\section{EXPLANATION OF PLATES I-IV}

\section{Plate I}

Minimal rumen papillary development (SEF mean: 4.09 $)$ ) in a field type roe deer sampled in winter (30.01.81); (1) dorsal ruminal wall, (2) atrium ruminis, (3) floor of dorsocaudal blindsac, (4) ventral ruminal wall. Enl.c.5 $\times$.

\section{Plate II}

Minimal rumen papillary development (SEF mean: $6.89 \times$ ) in a field type roe deer sampled during the vegetation period $(26.05 .81)$; (1) dorsal ruminal wall, (2) atrium ruminis, (3) floor of dorsocaudal blindsac, (4) ventral ruminal wall. Enl. c. $5 \times$.

\section{Plate III}

Maximal rumen papillary development (SEF mean: $16.55 \times$ ) in a forest type roe deer sampled during the vegetation period $(20.06 .81)$; (1) dorsal ruminal wall, (2) atrium ruminis, (3) floor of dorsocaudal blindsac, (4) ventral ruminal wall. Enl. c. $5 \times$.

Plate IV

Abnormally shaped rumen papillae from forest type roe deer sampled in summer (above) and from field type roe deer sampled in May. Rapid changes (budding) of the subepithelial vascular system result repeatedly in branching or multiple papillae (excessive epithelial cell proliferation) as signs of dramatic mucosal changes in reaction to changing nutritional conditions. 